\title{
Effect of dietary vegetable oil consumption on blood glucose levels, lipid profile and weight in diabetic mice: an experimental case-control study
}

\author{
Robert A. Ngala ${ }^{1 *}$, Isaac Ampong ${ }^{1}$, Samuel Asamoah Sakyi ${ }^{1,2}$ and Enoch Odame Anto ${ }^{1}$
}

\begin{abstract}
Background: Free fatty acids have been reported to impair insulin action; Dietary fat composition has been implicated in the development of insulin resistance as well as fasting glycaemia and type 2 diabetes mellitus. This work was designed to determine the benefits of consuming vegetable oils on the management of diabetes in diabetic mice.

Methods: Forty eight (48) maledb/db diabetic mice were randomly divided into eight groups of six. The first four groups were fed on chow (control), $10 \%$ Red palm oil feed, $10 \%$ groundnut oil feed, and $10 \%$ coconut oil feed. The second four groups were fed similar to the first four groups but in addition were administered glibenclamide (2 mg/kg -wt i.p) daily at 8. AM.

Results: Plasma glucose in the diabetic mice was significantly reduced after consuming diets fortified with $10 \%$ palm oil, groundnut oil and coconut oil and also in mice additionally treated with glibenclamide. In mice that were not treated glibenclamide, treatment with groundnut oil reduced total cholesterol and LDL-cholesterol and raised plasma HDL. Plasma triglycerides were unchanged. Palm oil and coconut oil had no effect on any of the plasma lipids. In mice that were treated glibenclamide, the control and palm oil treatment significantly reduced total cholesterol $(p<0.05)$. The control, groundnut oil, palm oil and coconut oil significantly $(p<0.05)$ reduced plasma LDL-cholesterol. HDL-cholesterol was raised in groundnut oil, and coconut oil. Plasma triglycerides were raised in only on groundnut oil.

Conclusion: Ten percent fortified vegetable oil feeds (red palm oil, groundnut oil and coconut oil) significantly improved lipid profile and significantly reduced blood glucose in diabetic mice. Groundnut oil raised HDL and lowered LDL even in mice given glibenclamide but it did not lower total cholesterol in mice given glibenclamide
\end{abstract}

Keywords: Palm oil, Groundnut oil, Coconut oil, Glibenclamide

\section{Background}

Increased plasma free fatty acids reduced insulinstimulated glucose-uptake. The mechanism responsible for this inhibition, however, remains unclear. There is sufficient evidence suggesting that the defects in glucose uptake and storage in the presence of free fatty acids may be related to abnormal fat metabolism $[1,2]$. Most

\footnotetext{
* Correspondence: rngala2000@yahoo.com

${ }^{1}$ Department of Molecular Medicine, School of Medical Science, Kwame Nkrumah University of Science and Technology (KNUST), Kumasi, Ghana Full list of author information is available at the end of the article
}

patients with type 2 diabetes are obese and have elevated plasma free fatty acids concentrations [3], and these have been shown to inhibit insulin-stimulated glucose uptake $[4,5]$. The Randle glucose-fatty acid cycle has been used to explain insulin resistance in skeletal muscle of patients with type 2 diabetes or obesity. An alternative hypothesis proposes that muscle insulin resistance results from decreased mitochondrial oxidation of fatty acids [6-9]. The unoxidized fatty acids are re-routed toward the synthesis of diacylglycerol and ceramide, which in turn stimulate stress-induced protein kinases that 
inhibit insulin signalling [8,9]. This hypothesis is supported by measurement of the concentrations of lipids in mitochondrial oxidative capacity, and the phosphorylation state of several components of the insulinsignalling pathway in hearts perfused with palmitate in pathological samples from type 2 diabetic patients [10].

Increasing evidence implicates dietary fat composition in the development of insulin resistance, including impaired fasting glycaemia and Type 2 diabetes mellitus [11, 12]. Several cross-sectional studies have shown an association between dietary saturated fat content and hyperinsulinaemia [13] impaired glucose tolerance [14, 15] and overt diabetes [16]. Groundnut oil contains 46 and $32 \%$ of mono unsaturated fatty acids (MUFA) and polyunsaturated fatty acids (PUFA), respectively Palm oil contains approximately $50 \%$ of saturated and $50 \%$ unsaturated fatty acids [17], whilst coconut oil is, a saturated fat which contains predominantly medium-chain saturated fatty acids with high antioxidant properties [18-20].

Several management strategies of diabetes such as dietary modification, exercise, oral hypoglycaemic agents, and insulin have been in used for decades. However, these regimen have not adequately proven to be effective in curbing the complications associated with diabetes mellitus [21]. Vegetable oils have also been found to be useful in the management of diabetes [22]. These oils contains different fractions of fat and other component such as tocotrienols, tocopherols, oryzanol, phytosterols which have varying effect on insulin resistance and metabolic control [23]. Many vegetable oils including groundnut oil, red palm oil, coconut oil and palm kennel oil are widely used in many developing countries as part of their dietary preparations. A favourable glucose response was also induced by fish oil feeding and this was mediated through body weight loss [24]. Noninsulin diabetic model mice fed on palm oil had improved glycaemic control despite their marked obesity [25]. However, public perception that intake of these edible oils contributes to dyslipidaemia and increase cardiovascular risk has reduced their consumption. It is against this background that this study was aimed at determining the metabolic effect of some vegetable oil consumption in the management of diabetes in diabetic mice.

\section{Methods}

All procedures and techniques used in this study were in accordance with the National Institute of Health Guide lines for the care of Laboratory Animals (NIH). Department of Health Service Publication No 83-23, revised 1985). The protocol for the study was approved by the Health Service Ethics committee, School of Medical Sciences, Kwame
Nkrumah University of Science and Technology KumasiGhana.

Forty eight (48) male diabetic mice (BKS.Cg-m $+/+$ Lepr $^{\mathrm{db}} /$ BomTac) strain each weighing between 25 and $40 \mathrm{~g}$ and a mean weight of $35 \mathrm{~g}$ and approximately 8 weeks old were obtained from the Department of Animal Experimentation, Nuguchi Memorial Institute for Medical Research, University of Ghana. The mice were transported in specialized cages and brought to the Animal house of the pharmacology Department, Kwame Nkrumah University of Science and Technology (KNUST)-Ghana where the study was carried out. The mice were housed in groups of two at $25-30{ }^{\circ} \mathrm{C}$ with $12 \mathrm{~h}$ daylight. The mice were fed ad libitum with normal rodent chow (composed of $21 \%$ protein, $5 \%$ fat and $34 \%$ carbohydrate, made from fish meal, maize, rice and wheat bran) was bought from the Nuguchi Memorial Institute for Medical Research laboratories (Department of Animal Experimentation) Accra - Ghana.

\section{Diet preparation}

The test diets were prepared by mixing $10 \mathrm{~g}$ vegetable oils with $90 \mathrm{~g}$ normal commercial rodent chow to obtain a $10 \%$ by weight of the vegetable oils. Three different $10 \%$ fat diets were prepared by adding red palm oil (extracted from the pulp of African oil palm (Elaeisguineensis), groundnut oil (extracted from the nuts of Arachishypogaea) and coconut oil (extracted from the kennel of Cocosnucifera) and pure chow as control diet and kept in a refrigerator until use. The supplementation in vegetable oils is in addition to the $5 \%$ fats that are in the $90 \%$ of the chow. The vegetable oils were bought from the Ghana Food Distribution Corporation. The red palm oil is composed of $51 \%$ saturated fatty acid, $39 \%$ monounsaturated fatty acids and $10 \%$ polyunsaturated fatty acids. The groundnut oil is composed of $18 \%$ saturated fatty acid, $48 \%$ monounsaturated fatty acids and $34 \%$ polyunsaturated fatty acids, whilst the coconut oil is composed of $92 \%$ saturated fatty acid, $6 \%$ monounsaturated fatty acids and $2 \%$ polyunsaturated fatty acids.

\section{Experimental design}

After one week of acclimatization, during which period mice were fed on normal chow ad libi tum, overnight fasting glucose levels were determined. Only mice whose fasting glucose was $\geq 11.0 \mathrm{mmol} / \mathrm{L}$ were selected for the experiment.

The selected animals were randomly divided into eight groups of six animals each:

Groups I-IV were on diet treatment only and group V-VIII, were additionally treated glibenclamide (2 $\mathrm{mg} / \mathrm{kg}$ body-wt, i.p) daily at $8.00 \mathrm{AM}$, for the 4 week period as follows) 
Group I: chow (control)

Group II: groundnut oil diet

Group III: palm oil diet

Group IV: coconut oil diet

Group V: Chow + glibenclamide (2 mg/kg b-wt)

Group VI: groundnut oil diet + glibenclamide $(2 \mathrm{mg} / \mathrm{kg}$ b-wt)

Group VII: palm oil diet + glibenclamide (2 mg/kg b-wt)

Group VIII: coconut oil diet + glibenclamides

(2 mg/kg b-wt)

\section{Biochemical assay}

After 28 days of treatment, the $12 \mathrm{~h}$-fasted animals were killed by cervical decapitation between 8 AM. and 9 AM. About $2.0 \mathrm{ml}$ of blood sample was taken from each mouse, of which $1.5 \mathrm{ml}$ was dispensed into a plain tube to clot whiles $0.5 \mathrm{ml}$ of the blood was put into separate EDTA tubes. The tubes were then placed in a centrifuge and spun at $3000 \mathrm{x} \mathrm{g}$ for 10 min to obtain the plasma and sera. Plasma glucose was measured immediately and the serum for the measurement of other biochemical variables was stored at $-80{ }^{\circ} \mathrm{C}$ until analysis.

Biochemical assays including glucose, Total cholesterol, LDL-cholesterol, HDL-cholesterol, triglycerides, were analysed using the automated analyser, Mindray Chemistry Analser (BS 120) (China) with reagent kits manufactured by the (ELITech Clinical System SAS 2.1 61500 SEES- FRANCE 2014-2010) compatible with the auto analyser, and according to the reagent kit manufacturer's protocol.

\section{Statistical analysis}

The data analysis was done using Graph Pad Prism version 5.00 for windows (GraphPad Software, San Diego California, USA). Baseline characteristics were expressed as mean \pm standard error of means (SEM). One-way analysis of variance (ANOVA) with Dunnett's test was used for multiple comparisons between metabolic groups. $P$ value $<0.05$ was considered significant.

\section{Results and discussion}

The management of type 2 diabetes mellitus includes the use of diet, exercise, oral hypoglycemic agents, and insulin. However, these remedies do not effectively prevent the complications of diabetes mellitus [21]. Extracts of many local medicinal plants have been successfully used in the management of diabetes [26]. Some dietary fats have also been reported to be effective in lowering blood glucose [16]. However, dietary fat may also have a negative effect on the lipid profile [27] which may negate the gains of glucose lowering.

Dietary fats differ in chain length and degree of unsaturation and this affects plasma lipoprotein constitution [28]. Serum cholesterol level increases when dietary carbohydrates are replaced by saturated fatty acids and decreases when carbohydrates are replaced by polyunsaturated fatty acids containing omega 3 [27]. Studies have suggested that the cholesterol-decreasing effect of polyunsaturated fatty acids affects both LDL and HDL cholesterol $[28,29]$. However, the mechanism by which these fats affect serum lipoproteins concentration is unclear. Plasma total cholesterol, and LDL (Table 1) were significantly $(p<0.05)$ reduced and HDL-cholesterol was increased in diabetic mice fed on the groundnut oil diet, whilst the palm oil and coconut oils diets did not have any significant effects. None of the diets significantly affected the plasma triglycerides level. This means that the consumption of these vegetable oils does not pose cardiovascular risk. This is supported by the low cardiovascular risk index (HDL-cholesterol/Total cholesterol) Tables 1 and 2 .

Humans and animal studies have shown that, saturated fat intake increases both LDL and high-density lipoprotein (HDL) cholesterol levels [30, 31]. The increased LDL is due to the inhibiting of LDL receptor activity and thus enhancing apolipoprotein (apo) B-containing lipoprotein production [32]. In contrast, intake of polyunsaturated fatty acids had a modest but significant LDL cholesterol-lowering effect [33]. The lowering of LDL cholesterol in mice fed with

Table 1 The effect of vegetable oil consumption on plasma lipid profile in diabetic Mice

\begin{tabular}{|c|c|c|c|c|c|}
\hline \multirow[b]{2}{*}{ Parameters } & \multirow[b]{2}{*}{ Control (C) } & \multicolumn{3}{|c|}{ Vegetable oil without Glibenclimide treatment } & \multirow[b]{2}{*}{$p$-value } \\
\hline & & Palm (PO) & Groundnut (GO) & Coconut (CO) & \\
\hline$\overline{\mathrm{TC}}(\mathrm{mmol} / \mathrm{l})$ & $3.72 \pm 0.10$ & $3.51 \pm 0.04$ & $3.18 \pm 0.02^{a}$ & $4.06 \pm 0.18^{b}$ & 0.0010 \\
\hline LDL (mmol/l) & $2.57 \pm 0.10$ & $2.37 \pm 0.06$ & $1.67 \pm 0.04^{\mathrm{ba}}$ & $2.90 \pm 0.20$ & 0.0187 \\
\hline $\mathrm{HDL}(\mathrm{mmol} / \mathrm{l})$ & $0.45 \pm 0.04$ & $0.45 \pm 0.04$ & $0.72 \pm 0.06^{\mathrm{ba}}$ & $0.42 \pm 0.04$ & 0.0252 \\
\hline TG $(\mathrm{mmol} / \mathrm{l})$ & $1.52 \pm 0.05$ & $1.50 \pm 0.04$ & $1.70 \pm 0.05$ & $1.60 \pm 0.11$ & 0.8973 \\
\hline $\mathrm{HDL} / \mathrm{TC}$ ratio & $0.12 \pm 0.001$ & $0.13 \pm 0.001$ & $0.23 \pm 0.001^{\mathrm{ba}}$ & $0.10 \pm 0.001$ & 0.0137 \\
\hline
\end{tabular}

Mean effect of vegetable oils on the lipid profile of diabetic mice. Mean value are expressed as mean \pm SEM. $N=6$ in each group. TC total cholesterol, $L D L$ low density lipoprotein, HDL high density lipoprotein, $T G$ triglycerides. ${ }^{a}$ indicate significant difference compared to controls, $p<0.05$, ${ }^{b}$ indicate significant difference compared to other vegetable oils. Total cholesterol, $L D L$, and LDL were significantly reduced in mice fed on groundnut oil diet only $(p<0.05)$, while $H D L$ was significantly increased 
Table 2 Effect of vegetable oils consumption and Glibenclamide treatments on serum lipid profile of diabetic mice

\begin{tabular}{lllllll}
\hline & & \multicolumn{3}{l}{ Vegetable oil + Glibenclamide treatment } & & \\
\cline { 3 - 7 } Parameters & Control (C) & Control + Glib & Palm +Glib & Groundnut +Glib & Coconut + Glib & $p$-value \\
\hline TC $(\mathrm{mmol} / \mathrm{l})$ & $3.72 \pm 0.10$ & $3.08 \pm 0.12^{\mathrm{a}}$ & $2.77 \pm 0.12^{\mathrm{a}}$ & $3.33 \pm 0.09^{\mathrm{b}}$ & $3.30 \pm 0.09^{\mathrm{b}}$ & 0.0019 \\
$\mathrm{LDL}(\mathrm{mmo} / \mathrm{l})$ & $2.57 \pm 0.10$ & $1.81 \pm 0.14^{\mathrm{a}}$ & $1.60 \pm 0.12^{\mathrm{a}}$ & $1.41 \pm 0.06^{\mathrm{a}}$ & $3.09 \pm 0.13^{\mathrm{ba}}$ & 0.0001 \\
$\mathrm{HDL}(\mathrm{mmol} / \mathrm{l})$ & $0.45 \pm 0.04$ & $0.58 \pm 0.03$ & $0.36 \pm 0.02$ & $0.75 \pm 0.04^{\mathrm{ba}}$ & $0.71 \pm 0.06^{\mathrm{ba}}$ & 0.0021 \\
$\mathrm{TG}(\mathrm{mmol} / \mathrm{l})$ & $1.52 \pm 0.05$ & $1.50 \pm 0.09$ & $1.76 \pm 0.08$ & $2.52 \pm 0.06^{\mathrm{ba}}$ & $1.60 \pm 0.10$ & 0.0313 \\
$\mathrm{HDL} / \mathrm{TC}$ ratio & $0.12 \pm 0.001$ & $0.19 \pm 0.001$ & $0.13 \pm 0.001$ & $0.23 \pm 0.001^{\mathrm{ba}}$ & $0.22 \pm 0.001^{\mathrm{ba}}$ & 0.0105 \\
\hline
\end{tabular}

Mean effect of vegetable oils consumption and Glibenclamide treatments onserum lipid profile of diabetic mice. Values are expressed as mean \pm SEM. $N=6$ in each group. $T C$ total cholesterol, $L D L$ low density lipoprotein, $H D L$ high density lipoprotein, $T G$ triglycerides Glib glibenclamide. ${ }^{a}$ indicate significant difference

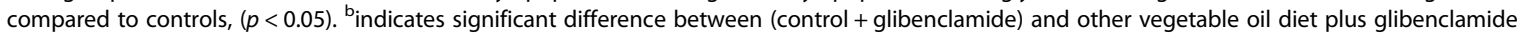

groundnut oil diet is consistent with other findings, particularly considering the fact that groundnut oil predominantly consists of polyunsaturated fatty acids [17]. In this study groundnut oil significantly ( $p$ $<0.05$ ) raised plasma HDL contrary to findings by Mattson and Grundy which suggest that polyunsaturated fatty acids lower HDL [34]. Similar results to our finding have been reported: streptozotocininduced diabetes in rats lowered HDL-cholesterol whilst $8 \%$ groundnut oil raised plasma HDL in streptozotocin-induced diabetic rats [35]. This may be because diabetes has a metabolic defect which is compensated for by an increase in HDL levels.

The exact mechanism by which groundnut oil raised HDL levels in the diabetic rats is not understood.

When the mice in addition to the oil feed diet were administered with $(2 \mathrm{mg} / \mathrm{kg}$. wt. glibenclamide i.p) daily for the 4 week period, plasma Total cholesterol was significantly $(p<0.05)$ reduced in the control and mice fed on palm oil diet. Plasma LDL levels in diabetic mice were significantly $(p<0.05)$ reduced in all the oil diets and the control plus glibenclamide treatment. HDL was significantly $(p<0.05)$ increased only in groundnut oil and coconut oil formulated diets. Triglycerides were only significantly $(p<0.05)$ increased in the groundnut oil diet (Table 2). It is unclear how glibenclamide treatment increases triglyceride lipid subfraction while the others are reduced. To consider the effect of the oils on treatment with glibenclamide, the lipid levels were compared to the control plus glibenclamide treatment. Total cholesterol was significantly increased by groundnut oil and coconut oil. LDL was significantly raised in the coconut oil. HDL was increased only in the groundnut oil and coconut oils, while triglycerides were also significantly increased only in the groundnut oil. Even though total cholesterol was increased in the groundnut and coconut oil there was a corresponding significant decrease in cardiovascular risk (Tables 1 and 2).
Mice fed on groundnut oil, palm oil and coconut oil diets had significant $(p<0.05)$ reduction in blood glucose. The reduction in blood glucose in groundnut oil diet-fed mice may be due to the presence of mono unsaturated fatty acids (MUFA) [36]. A reduction in plasma glucose concentration with the consumption of a MUFA-rich diet has been reported [37]. Indeed it has also been shown that when the groundnut oil was replaced with sesame oil (a much higher percentage polyunsaturated fatty acid than groundnuts) the reduction in glucose was even more significant [38].

Ikemoto et al., attributed reduction of blood glucose in mice fed on palm oil to palm oil-induced hypersinsulineamia [25]. The high antioxidant effect of both processed and unprocessed palm oil which could also lead to reduced blood glucose is due to the carotenoids, phosphatides, sterols, tocopherols and trace metals content, and these have been shown to be effective against oxidative stress in in vitro and in vivo studies [39]. The carotenoids, together with vitamin E, ascorbic acid, enzymes and proteins, are members of the biological antioxidant network converting highly reactive radicals and free fatty peroxyl radicals to less active species [40] thus, protecting against oxidative damage to cells. $\beta$-carotene is the most abundant carotenoids which can be converted to vitamin A; which is important in the visual process. In addition, it is an antioxidant that destroys singlet oxygen and free radicals [41]. Oral administration of antioxidants extracts from Aloe vera gel significantly decreased the levels of blood glucose, glycosylated hemoglobin and increased haemoglobin levels [42]. Several other studies have shown that antioxidants administration indeed reduces blood glucose, glycosylated haemoglobin and the upregulation of oxidative stress enzymes in diabetic animals $[42,43]$. The administration of coconut oil diet, even though coconut oil is a saturated fat, significantly reduced blood glucose. The exact mechanism is not understood. This could also be mediated through its antioxidant effect [44]. Indeed Houssay and, Martínez showed that 
administration of coconut oil completely protected against diabetes [45].

In a Post Hoc Multiple Comparisons analysis (Fig. 1), plasma glucose in the glibenclamide treated diabetic mice was surprisingly significantly higher in the palm oil diet and groundnut oil diet fed mice than in the non glibenclimide treated mice on palm oil diet and groundnut oil diet $(p<0.05)$. The values were however significantly lower than in the control. On the other hand, plasma glucose in the glibenclamide treated mice on coconut oil diet was significantly decreased $(p<0.05)$ compared to the coconut oil diet only fed mice (Fig. 1).

Sulfonylurea, such as glibenclamide has been widely used to treat type 2 diabetic patients over a long period. (Glibenclamide was chosen in this study because it is one of the antidiabetic drugs recommended by the Ministry of Health- Ghana for the management of diabetes). The mechanism of action of this drug has been so controversial. However; all do agree that the hypoglycaemic effect is mediated through increased insulin secretion [46]. Free fatty acids have been shown to impair insulin sensitivity [47]. The effect of fatty acids on sulfonylureas may be varied. Palm oil and groundnut oil had inhibitory effect on glibenclamide activity, hence plasma glucose was significantly $(p<0.05)$ higher in mice fed on these oils plus glibenclamide treatment than mice on the oils feeds alone (Fig. 1). Zambon et al., showed similar effect of fish oil $(\omega 3)$ on glyburide. Fish oil alone significantly reduced blood glucose. However when the Fish oil was administered together with glyburide, the hypoglycaemic effect was reduced [48]. The mechanism by which these vegetable oils partially impair the activities of glibenclamide and fish oil impairs glyburide is unclear. It may be that these oils partially impair the activity of the glibenclamide-induced insulin secretion, as suggested by Boden [47]. However, the effect of coconut oil on glibenclamide activity was additive. The hypoglycaemic effect of glibenclamide plus coconut oil alone was significantly $(p<0.05)$ higher than the effect of coconut alone (Fig. 1). Coconut oil may therefore induce insulin secretion that may argument the insulin secretion induced by glibenclamide or at least improves insulin sensitivity, or the effect may be mediated through some other mechanism.

Food consumption rate was determined by the amount of food intake per kilogram body weight of the mice. Even though there was no significant change in food consumption per gram weight of mice compared to the control, there was a consistent tendency for decreased consumption of the oil formulated diets compared to the control chow (Fig. 2). Recent studies have shown that body weight loss can be achieved by increase in fat intake, which is mediated through early satiety or filling, resulting in lower total calorific intake compared to a carbohydrate diet that would require high filling and higher calories [49].

This non-significant reduction in food consumption corresponded with a nonsignificant body weight loss. (Table 3). Since growth rate is time dependent, it is possible that the reduction in food consumption and

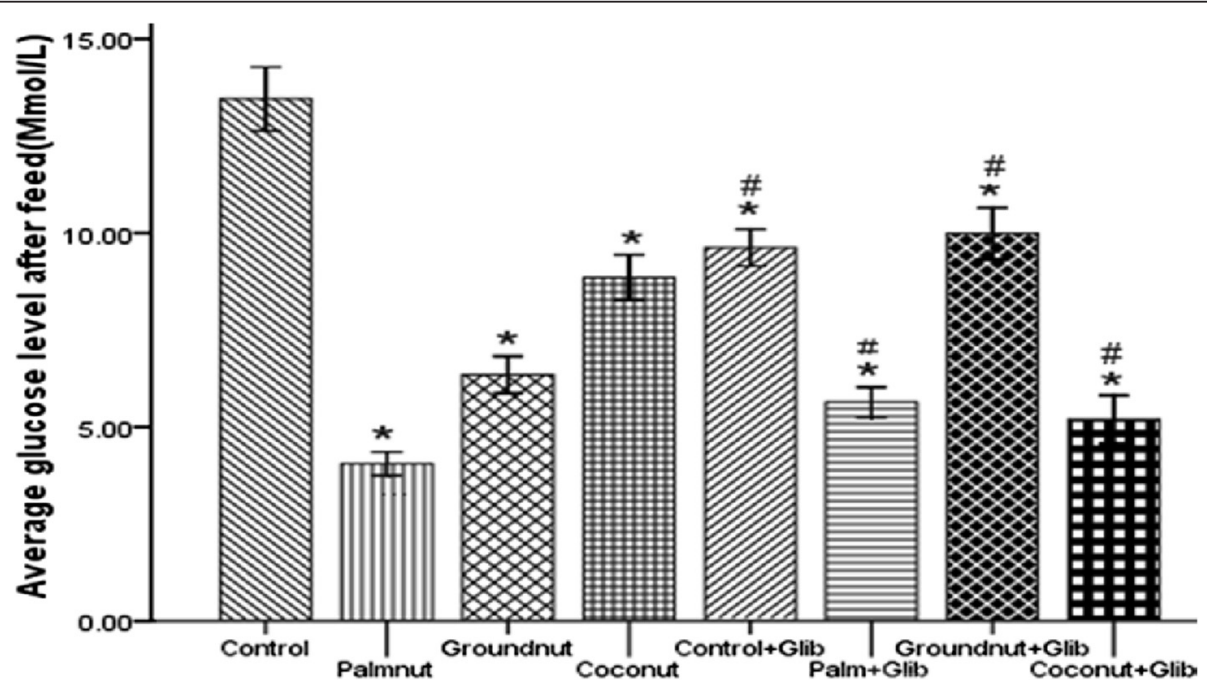

Fig. 1 The effect of vegetable oil consumption on glibenclamide activity in diabetic Mice. Mean effect of vegetable oils on glucose level on diabetic mice after oil diet feed. * indicate significant difference compared to controls, $(p<0.05)$. Mean value were significantly different from the control group. \# indicate significant difference compared to other vegetable oils $(p<0.05)$. Mean value were significantly different from its comparative vegetable oil only ( ${ }^{P} P<0.05, \# P<0.05$, Post Hoc Multiple Comparisons) 


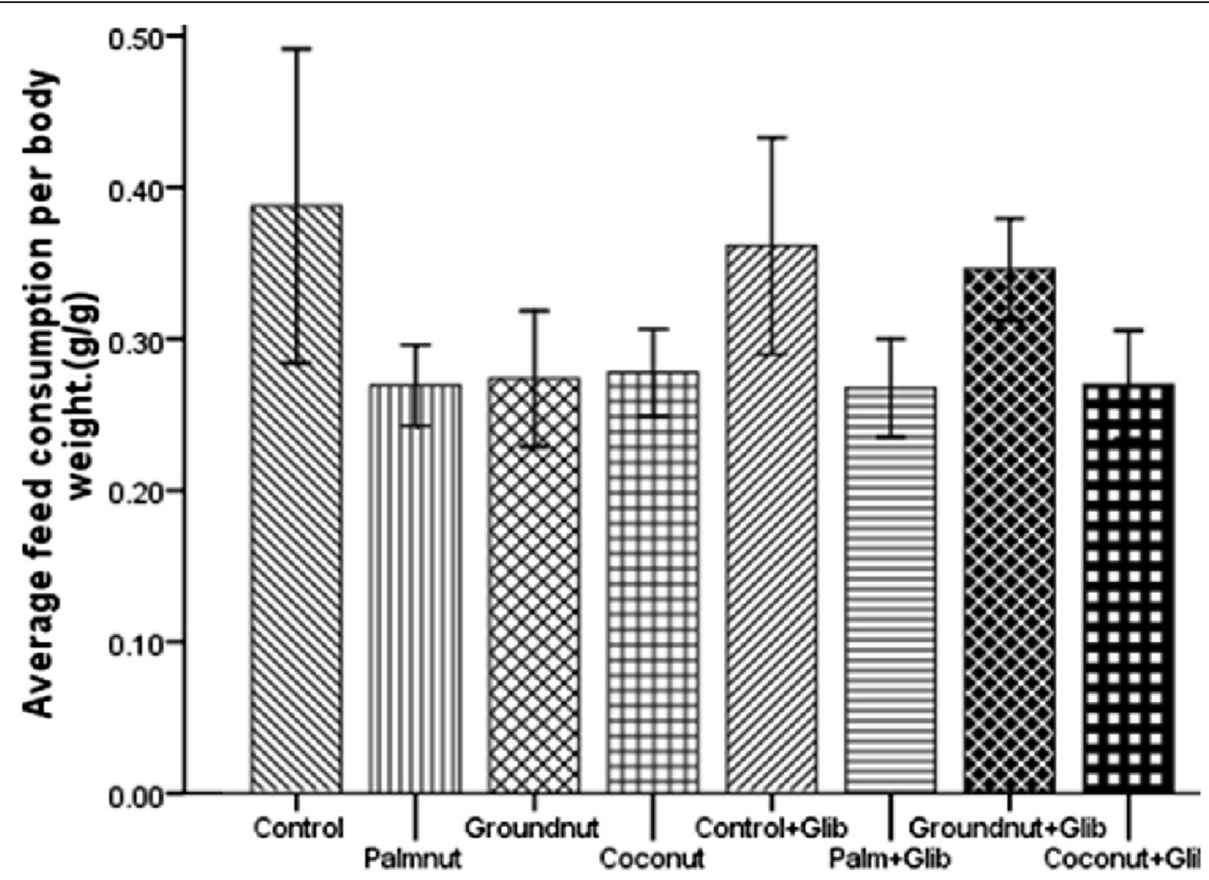

Fig. 2 The effect of vegetable oil consumption on food intake in diabetic Mice. Mean effect of vegetable oils on feed consumption per body weight for diabetic mice. *Mean value were nonsignificantly different from the control group ${ }^{*} P<0.05$,Post Hoc Multiple Comparisons)

body weight loss would have become significant if the period of study had been extended to six or more weeks as has been reported by Danqua.et al. [50].

\section{Conclusion}

There was significant improvement of lipid profile in diabetic mice fed on $10 \%$ vegetable oil fortified meal. Total cholesterol was significantly reduced in mice fed on groundnut oil only and palm oil diets plus glibenclamide treatment. Palm oil and groundnut oil diets and coconut oil plus glibenclamide treatment significantly reduced plasma LDL levels in mice fed on the diets. HDL cholesterol was significantly increased in mice on groundnut oil diets only. Plasma glucose in the diabetic mice was significantly reduced after consuming diets fortified with $10 \%$ palm oil, groundnut oil and coconut oil. $10 \%$ Groundnut oil, palm oil and coconut oil feeding had antidiabetic properties with no cardiovascular risk in diabetic mice.

Table 3 Effect of vegetable oil diet on weight of diabetic mice

\begin{tabular}{lll}
\hline Groups/treatments & Mean weight (g) & p-value compared to control(C) \\
\hline Control (C) (chow) & $0.39 \pm 0.01$ & 0.5981 \\
Vegetable oil without Glibenclamide & & 0.5981 \\
$\quad$ Palm (PO) diet & $0.27 \pm 0.00$ & 0.7139 \\
Groundnut (GO) diet & $0.27 \pm 0.00$ & 0.9014 \\
Coconut (CO) diet & $0.28 \pm 0.00$ & 0.5981 \\
Vegetable oil + Glibenclamide (Glib) & & 0.7881 \\
Control (chow) + Glib & $0.36 \pm 0.00$ & 0.5981 \\
Palm oil diet + Glib & $0.27 \pm 0.00$ & $0.34 \pm 0.00$ \\
Groundnut oil diet + Glib (GO +G) & $0.27 \pm 0.00$ & \\
Coconut oil diet + Glib (CO +G)
\end{tabular}

Effect of vegetable oil diet on weight gain of diabetic mice. Values are presented as Mean + SEM. $N=6$ in each group. There was no significant weight gain in the diabetic mice on all the vegetable oil formulated diets compared to the control mice on chow only $(P<0.05$, Post Hoc Multiple Comparisons) 


\section{Abbreviations}

CO: Coconut oil; GO: Groundnut oil; PO: Palm oil.

\section{Competing interests}

The authors' declare that they have no competing interests.

\section{Authors' contributions}

RAN developed the concept and design of the study and coordinated the data collection and prepared the manuscript for publication. SAS assisted in critically reviewing the proposal design of the study, and data analysis. IA generated the data for the work and assisted in analysis and interpretation of the data. EON participated in analysis and interpretation of the data. All authors read and approved the final manuscript.

\section{Acknowledgement}

Isaac Ampong was supported by the Ghana Education Trust Fund through the Kwame Nkrumah University of Science and Technology, Kumasi- The authors are also grateful to the laboratory staff of the School of Pharmacy, Kwame Nkrumah University of Science and Technology, for providing space in the animal laboratory and helping to maintain the mice.

\section{Author details}

'Department of Molecular Medicine, School of Medical Science, Kwame Nkrumah University of Science and Technology (KNUST), Kumasi, Ghana. 2Department of Bacteriology, Noguchi Memorial Institute for Medical Research, Accra, Ghana.

\section{Received: 29 July 2015 Accepted: 19 February 2016}

\section{Published online: 27 May 2016}

\section{References}

1. McGarry JD. What if Minkowski had been ageusic? An alternative angle on diabetes. Science. 1992;258(5083):766-70.

2. Randle P, Garland P, Newsholmet E, Hales C. The glucose fatty acid cycle in obesity and maturity onset diabetes mellitus. Ann N Y Acad Sci. 1965;131(1): 324-33.

3. Reaven GM, Hollenbeck C, Jeng C-Y, Wu MS, Chen Y-DI. Measurement of plasma glucose, free fatty acid, lactate, and insulin for $24 \mathrm{~h}$ in patients with NIDDM. Diabetes. 1988;37(8):1020-4

4. Thiébaud D, DeFronzo RA, Jacot $E$, Golay A, Acheson $K$, Maeder $E$, Jéquier $E$, Felber J-P. Effect of long chain triglyceride infusion on glucose metabolism in man. Metabolism. 1982;31(11):1128-36.

5. Saloranta C, Koivisto V, Widen E, Falholt K, DeFronzo R, Harkonen M, Groop L. Contribution of muscle and liver to glucose-fatty acid cycle in humans. Am J Physiol Endocrinol Metab. 1993;264(4):E599-605.

6. Kelley DE, He J, Menshikova EV, Ritov VB. Dysfunction of mitochondria in human skeletal muscle in type 2 diabetes. Diabetes. 2002;51(10):2944-50.

7. McGarry JD. Glucose-fatty acid interactions in health and disease. Am J Clin Nutr. 1998:67(3):500S-4S

8. Morino K, Petersen KF, Shulman Gl. Molecular mechanisms of insulin resistance in humans and their potential links with mitochondrial dysfunction. Diabetes. 2006;55(2):S9-S15.

9. Savage DB, Petersen KF, Shulman Gl. Disordered lipid metabolism and the pathogenesis of insulin resistance. Physiol Rev. 2007:87(2):507-20.

10. Harmancey R, Wilson CR, Taegtmeyer H. Adaptation and maladaptation of the heart in obesity. Hypertension. 2008;52(2):181-7.

11. Colditz GA, Manson J, Stampfer MJ, Rosner B, Willett WC, Speizer FE. Diet and risk of clinical diabetes in women. Am J Clin Nutr. 1992:55(5):1018-23.

12. Parker DR, Weiss S, Troisi R, Cassano P, Vokonas P, Landsberg L. Relationship of dietary saturated fatty acids and body habitus to serum insulin concentrations: the normative aging study. Am J Clin Nutr. 1993;58(2):129-36.

13. Marshall J, Bessesen D, Hamman R. High saturated fat and low starch and fibre are associated with hyperinsulinaemia in a non-diabetic population: the San Luis valley diabetes study. Diabetologia. 1997;40(4):430-8.

14. Feskens EJ, Virtanen SM, Räsänen L, Tuomilehto J, Stengård J, Pekkanen J, Nissinen A, Kromhout D. Dietary factors determining diabetes and impaired glucose tolerance: a 20-year follow-up of the Finnish and Dutch cohorts of the seven countries study. Diabetes Care. 1995;18(8):1104-12.

15. Feskens EJ, Kromhout D. Habitual dietary intake and glucose tolerance in euglycaemic men: the Zutphen Study. Int J Epidemiol. 1990;19(4):953-9.
16. Marshall JA, Bessesen DH, Hamman RF. High saturated fat and low starch and fibre are associated with hyperinsulinaemia in a non-diabetic population: The San Luis Valley Diabetes Study. Diabetologia. 1997:40(4):430

17. Che Man YB, Haryati T, Ghazali HM, Asbi B. A composition and thermal profile of crude palm oil and its products. J Am Oil Chem Soc. 1999;76(2): 237-42.

18. Marina MA, Che Man YB, Nazimah SAH, Amin I. Chemical Properties of Virgin Coconut Oil. J Am Oil Chem Soc. 2009;86(4):301-7.

19. Blackburn G, Kater G, Mascioli E, Kowalchuk M, Babayan V, Bistrian B. A reevaluation of coconut oil's effect on serum cholesterol and atherogenesis. J Philipp Med Assoc. 1989;65:144-52.

20. Amarasiri W, Dissanayake A. Coconut fats. Ceylon Med J. 2006;51(2):47-51.

21. Palumbo P: Glycemic control, mealtime glucose excursions, and diabetic complications in type 2 diabetes mellitus. In: Division of Endocrinology and Internal Medicine, Mayo Clinic, Scottsdale, Ariz. Mayo Clinic Proceedings: 2001: Elsevier; 2001: 609-618

22. Evert AB, Boucher JL, Cypress M, Dunbar SA, Franz MJ, Mayer-Davis EJ, Neumiller JJ, Nwankwo R, Verdi CL, Urbanski P, Yancy Jr. WS. Nutrition Therapy Recommendations for the Management of Adults With Diabetes. Diabetes Care. 2014;37(1):S120-S143.

23. Gupta A, Nigam A. Edible oils: an overview with diabetes perspective J Pharm Pharm Sci. 2015;4(8):596-613.

24. Mori TA, Bao DQ, Burke V, Puddey IB, Watts GF, Beilin LJ. Dietary fish as a major component of a weight-loss diet: effect on serum lipids, glucose, and insulin metabolism in overweight hypertensive subjects. Am J Clin Nutr. 1999:70(5):817-25

25. Ikemoto S, Takahashi M, Tsunoda N, Maruyama K, Itakura H, Ezaki O. High-fat diet-induced hyperglycemia and obesity in mice: differential effects of dietary oils. Metabolism. 1996;45(12):1539-46.

26. Joy K, Kuttan R. Anti-diabetic activity of Picrorrhiza kurroa extract. J Ethnopharmacol. 1999;67(2):143-8.

27. Hegsted D, McGandy R, Myers M, Stare F. Quantitative effects of dietary fat on serum cholesterol in man. Am J Clin Nutr. 1965;17(5):281-95.

28. Woollett LA, Spady DK, Dietschy JM. Saturated and unsaturated fatty acids independently regulate low density lipoprotein receptor activity and production rate. J Lipid Res. 1992;33(1):77-88.

29. Rose D, Richards R. Food store access and household fruit and vegetable use among participants in the US food stamp program. Public Health Nutr. 2004;7(08):1081-8.

30. Siri-Tarino PW, Sun Q, Hu FB, Krauss RM. Saturated fat, carbohydrate, and cardiovascular disease. Am J Clin Nutr. 2010:91(3):502-9.

31. Eqbal D, Halimah Abdullah S, Aminah A, Zalifah Mohd K: Effect of different vegetable oils (red palm olein, palm olein, corn oil and coconut oil) on lipid profile in rat. Food Nutr Sci. 2011;2(4):Paper ID 5212. 6 pages.

32. Dietschy JM. Dietary fatty acids and the regulation of plasma low density lipoprotein cholesterol concentrations. J Nutr. 1998;128(2):444S-8S.

33. Mensink RP, Martijn BK. Effect of dietary fatty acids on serum lipids and lipoproteins a meta-analysisof 27 trials. Arterioscler Thromb. 1992;12: 911-9.

34. Mattson FH, Grundy SM. Comparison of effects of dietary saturated, monounsaturated, and polyunsaturated fatty acids on plasma lipids and lipoproteins in man. J Lipid Res. 1985;26(2):194-202.

35. Ramesh B, Saravanan R, Pugalendi K. Effect of dietary substitution of groundnut oil on blood glucose, lipid profile, and redox status in streptozotocin-diabetic rats. Yale J Biol Med. 2006;79(1):9.

36. Rasmussen OW, Thomsen C, Hansen KW, Vesterlund M, Winther E, Hermansen K. Effects on blood pressure, glucose, and lipid levels of highmonounsaturated fat diet compared with a high-carbohydrate diet in NIDDM subjects. Diabetes Care. 1993;16(12):1565-71.

37. Mokuda O, Sakamoto Y, Hu H, Kawagoe R, Shimizu N. Effects of long chain free fatty acids on glucose-induced insulin secretion in the perfused rat pancreas. Horm Metab Res. 1993:25(11):596.

38. Ramesh B, Saravanan R, Pugalendi K. Influence of sesame oil on blood glucose, lipid peroxidation, and antioxidant status in streptozotocin diabetic rats. J Med Food. 2005;8(3):377-81.

39. American Diabetes Association AD. Nutrition recommendations and principles for people with diabetes mellitus. Diabetes Care. 2000;23:S43.

40. Ogugua V, Ikejiaku C. Effects of Palm oil on some oxidative indices of alloxan induced diabetic rabbits. Animal Res Int. 2008;2(1):227-30.

41. Edem D, Akpanabiatu M. Effects of palm oil-containing diets on enzyme activities of rats. Pak J Nutr. 2006;5(4):301-5. 
42. Rajasekaran S, Sivagnanam K, Subramanian S. Antioxidant effect of Aloe vera gel extract in streptozotocin-induced diabetes in rats. Pharmacol Rep. 2005; 57(1):90-6.

43. Rahimi R, Nikfar S, Larijani B, Abdollahi M. A review on the role of antioxidants in the management of diabetes and its complications. Biomed Pharmacother. 2005;59(7):365-73.

44. Nevin K, Rajamohan T. Virgin coconut oil supplemented diet increases the antioxidant status in rats. Food Chem. 2006;99(2):260-6.

45. Houssay B, Martinez C. Experimental diabetes and diet. Sci. 1947;105(2734): 548-9.

46. Lehtihet M, Welsh N, Berggren P-O, Cook GA, Sjöholm Å. Glibenclamide inhibits islet carnitine palmitoyltransferase 1 activity, leading to PKCdependent insulin exocytosis. Am J Physiol Endocrinol Metab. 2003;285(2): E438-46.

47. Boden $\mathrm{G}$. Role of fatty acids in the pathogenesis of insulin resistance and NIDDM. Diabetes. 1997;46(1):3-10.

48. Zambon S, Friday KE, Childs MT, Fujimoto WY, Bierman EL, Ensinck JW. Effect of glyburide and omega 3 fatty acid dietary supplements on glucose and lipid metabolism in patients with non-insulin-dependent diabetes mellitus. Am J Clin Nutr. 1992;56(2):447-54.

49. Swinburn BA, Seidell JC, James WP. Diet, nutrition and the prevention of excess weight gain and obesity. Public Health Nutr. 2004;7(1a):123-46.

50. Danquah CA, Koffuor GA, Annan K, Ketor EC. The anthelmintic activity of vernonia amygdalina (asteraceae) and alstonia Boonei de wild (apocynaceae). J Med Biomed Sci. 2012;1(1):21-7.

\section{Submit your next manuscript to BioMed Central and we will help you at every step:}

- We accept pre-submission inquiries

- Our selector tool helps you to find the most relevant journal

- We provide round the clock customer support

- Convenient online submission

- Thorough peer review

- Inclusion in PubMed and all major indexing services

- Maximum visibility for your research

Submit your manuscript at www.biomedcentral.com/submit

) Biomed Central 